\title{
Integration of Water and Energy Planning to Promote Sustainability
}

\author{
Priscila Carvalho*1, Catalina Spataru $^{2}$, Raimund Bleischwitz ${ }^{3}$ \\ ${ }^{1}$ Energy Institute, University College London, 14 Upper Woburn Place, London, United Kingdom \\ e-mail: priscila.carvalho.12@ucl.ac.uk \\ ${ }^{2}$ Energy Institute, University College London, 14 Upper Woburn Place, London, United Kingdom \\ e-mail: c.spataru@ucl.ac.uk \\ ${ }^{3}$ Institute for Sustainable Resources, University College London, 14 Upper Woburn Place, London, \\ United Kingdom \\ e-mail: r.bleischwitz@ucl.ac.uk
} Cite as: Carvalho, P., Spataru, C., Bleischwitz, R., Integration of Water and Energy Planning to Promote Sustainability,
J. sustain. dev. energy water environ. syst., 7(2), pp 229-252, 2019, DOI: https://doi.org/10.13044/j.sdewes.d6.0246

\begin{abstract}
This paper examines the inter-linkages between the water and energy sectors and their planning processes, by describing a comprehensive analytical tool developed to evaluate water energy nexus operational cost trends and planning to assist decision makers in exploring and evaluating alternative courses of action. Brazil has been chosen as a case study, because its electricity production is highly dependent on water to keep affordable tariffs, which in turn also serves as input to other important sectors, such as water services and sanitation, and raises disputes especially in basins marked by water scarcity, such as the São Francisco basin. In light of hydrological factors (e.g., droughts) and non-hydrological factors (e.g., chronic delays in delivery of new plants) there has been water availability constraints for electricity generation and energy prices have risen, while water quantity and quality have decreased for multiple users. Both of which impact negatively on water services and sanitation providers, because electricity figures as their fastest growing costs in times when they need more energy to source water from longer distances, or deeper levels because of water quantity and quality issues. Energy and water are characterized as common pool resources with planning processes along silos in Brazil that do not serve well the purpose of sustainable development. Better integrated water-energy plans at basin level is the alternative proposed under this paper to advance sustainability and mitigate the risks related to water scarcity that have resulted in negative impacts on both electricity and water sectors.
\end{abstract}

\section{KEYWORDS}

Analytical tool, Brazil, Integrated planning, Sustainable development goals, Water-energy nexus.

\section{INTRODUCTION}

The operational-resource interdependency between Water and Energy (WE) is a subject of several nexus studies that look into the complex interactions between them, which traditionally were based on silo thinking. Most studies have analysed quantitatively the trade-offs in resource use between WE, because water is used, consumed, and degraded to produce and deliver energy, while energy is necessary to secure, treat, distribute and

\footnotetext{
* Corresponding author
} 
deliver water. This way, there are competing interests and trade-offs to be considered between them. For instance, Carillo and Frei [1] quantified both the water withdrawal and consumption for energy purposes in Spain to find out that hydropower is the most water intensive source of energy. Hydropower plants are highly water intensive, because large volumes of water evaporate from the increased reservoir surface [2]. Nevertheless, sustainable multi-purpose use dams have the potential to support the management of water for multiple uses. Conflicts are raised to the extent that it is necessary to store water in reservoirs in benefit of energy security and affordable energy, while it is also necessary to promote minimum levels of water flow downstream of these developments in benefit of multiple water users. Countries like Brazil are greatly dependent on hydroelectric power (63\% of total installed capacity [3]) and in the past 15 years have experienced depletion of its reservoirs, with power shortages, rising electricity costs and issues of water quantity and quality that result in negative consequences to both the WE sectors. On the other hand, thermal power plants also require water for fuel extraction and processing, likewise for cooling down of systems at power stations, which are more or less water intensive depending on the source and dry cooling technologies [2]. Nuclear plants use the most water, followed by coal and waste-incineration plants and natural gas plants [4]. In France, the electricity industry withdrew and consumed $65 \%$ of the total water supply in 2010 and estimates show that by 2040 it will rise to $80 \%$ [5]. More than 18 billion cubic meters of water are required for nuclear operations, which uses more freshwater than agriculture and industry [6]. In extremely hot seasons like in 2003, France was forced to reduce its energy load (7-15\% reduction of its nuclear electricity supply) because water quantity was not sufficient to cool down nuclear systems [7]. In the United States around $80 \%$ of the electricity is sourced by thermoelectricity and withdrawal of water for cooling represents $44 \%$ of water withdrawn nationally [8]. Although dry-cooling technologies exist, they increase capital costs and can result in losses of efficiency [9]. The more the energy sector relies on water, the greater the vulnerability of energy generation to competing uses of water and water scarcity [8]. For example, expanding bioenergy to advance renewable energy targets adds additional pressure on freshwater footprint and may increase water stress on ecosystems and food production [10]. Water footprints of biomass have been estimated to be in the range of 24-243 $\mathrm{m}^{3}$ [11]. Semertzidis et al. [12] concluded that if sugarcane crops were to require irrigation in Brazil, the water intensity of these bioenergy crops in terms of "average crop water use" would increase from 9,627 to $15,942 \mathrm{~m}^{3} / \mathrm{ha} / \mathrm{yr}$. The expansion of biomass and biofuel crops to areas with lower precipitation levels will necessarily raise irrigation needs and disputes between multiple water users.

On the other hand, the water sector's reliance on centralised water-dependent electricity also raises its vulnerability connected to water-stress even further. The interdependency is particular important in water-stressed areas, because both hydroelectric and thermal power are highly dependent on water to produce electricity, while these areas also increasingly depend on energy-intensive water services. More energy is also gradually needed for wastewater treatment to the levels that will promote sustainable management of water resources. For example, in the European Union the Water Framework Directive requires 'good ecological status' for all surface, inland and coastal water, which in turn will increase energy use for wastewater treatment by almost $100 \%$ [13]. $11 \%$ of the World's hydroelectric capacity and $47 \%$ of world's thermal power capacity are in highly water-stressed areas [14]. Under some scenarios, water demand from the power sector is expected to grow worldwide, in Latin America by $360 \%$ by 2050, in Africa by $500 \%$ and in Asia up to $350 \%$ based on 2010 figures [15]. A rise is projected on water stress in many regions due to climate change and population growth, aggravated by increases of water demands for industry, cities and agriculture, which will require greater amounts of energy for strategies such as water transfers, 
desalination and pumping of water from underground levels. For example, in the Middle East and North Africa region the water supply strategies such as ground water pumping consumes $9 \%$ of total annual electrical consumption in Saudi Arabia, while desalination accounts for 5-12\% of total electricity consumption in the Arabian Gulf [16]. In Australia, the adaptation to water scarcity in many areas has increased energy consumption and greenhouse gas emissions [17].

At the core of W-E nexus research is the understanding of critical trade-offs, competing demand and identification of synergies and gaps for a more cohesive resource governance in benefit of security of supply and efficiency. Understanding the causes and the complex interaction between WE requires a broad understanding of various factors including management, policies and planning that governs WE resources. Most W-E nexus studies focus on the technical approach to understand the physical connections of resource use between competing users. There are some studies that have moved into the realm of resource governance, planning and policy adaptation. Sovacool [18] suggests that 'electricity-water crisis areas' can serve as useful policy tools. Siddiqi et al. [19] argue that integrated policy and planning is necessary to meet challenges of energy and water in Jordan. They recommend boundary-spanning intermediaries as the way forward by leveraging existing links between agents and organizations, or by merging existing organizations of distinct domains to create a new integrated entity and achieve the necessary linkages in future resource development strategies [19]. King et al. [20] argue that the first obstacle that needs to be addressed for better integrated energy-water policies is the informational challenge. This can be improved through well-structured databases and reporting requirements. A cross-sector perspective can help avoid policies that rather shift an issue from one sector to the other, instead of solving it [20]. For instance, Kumar [21] analysed the issues of insufficient supply of WE in environmentally sensitive hill towns in India and proposed regulatory interventions related to both that could be incorporated into building regulations. Scott et al. [22] argue that it isn't just a matter of planning for optimal resource use, but one of redesigning water-intensive power generation and energy-intensive water supply technology to reduce mutual impacts through policies that consider their joint management and help unlock potential of conservation, efficiency and renewable resources. Peel [23] brings forward the common elements that can be extracted from literature to advance integrated policy issues, which include:

- The need of multiple policy instruments that go beyond market-based approaches to promote integration;

- Distribution of power between scales with a preference to decentralised systems;

- Broad participation of multiple stakeholders;

- Well-developed information and tools such as robust planning;

- Move towards a more adaptive decision making approach with a focus on adaptation over time.

Pittock et al. [24] conclude that only integrated and multi-objective planning can deliver a more fair and equitable access to resources despite the contrasts among scale and trade-offs between water, energy and food. Bach et al. [25] recommend a basin-wide perspective for integration by encouraging a cooperative management through multi-stakeholder dialogue and discussions of risks.

In general, authors highlight the need for co-management across sectors of water and energy, whereby joint planning, policies and solutions could make action more sustainable and cost-efficient. The three main perspectives to advance nexus governance are technical, administrative and political [26]. The dominant technical-administrative approach focuses on risks, security and economic rationales. While the third perspective considers that addressing trade-offs is a political process that should be negotiated 
amongst multiple stakeholders [26]. In light of the limitations involving these current perspectives there are identifiable gaps. This paper contributes to the literature by proposing an analytical tool to capture $\mathrm{W}$-E nexus operational cost trends and also support better integrated planning at basin level due to issues of water quantity and quality. As recognised by Gassert et al. [27] more detailed, locally sourced data should be considered when assessing water-related risks and supporting decision-making processes. As a case study we considered Brazil because of its dependency on hydropower and the drought events over the past ten years which stressed the problems in terms of energy and water governance and planning.

\section{BACKGROUND AND MOTIVATION}

Population growth, urbanisation and industrialisation intensify WE's interactions and the need for considering their trade-offs. By 2035, global energy use will increase between 35-40\% [28]. Consumption in emerging economies like Brazil, China and India are expected to double by 2035 [29] (World Energy Council, 2010). The International Energy Agency projected that withdrawals for power plants will increase $35 \%$ and reach up 790 billion cubic metres, whereby 130 cubic metres would be consumed and never returned to the local hydrological cycle [29]. Water is also necessary for agriculture, industrial processes and human consumption, with the highest demands for drinking water, sanitation and drainage under urban centres. Forecast shows that $68 \%$ of the world's population will be living in urban centres by 2050 [30]. All of which, will raise demands for both energy and water and increase pressure on resources, land use, hydrology, carbon emissions, water reserves and the environment. Climate change creates an additional pressure because it impacts on precipitation levels, frequency of floods and droughts, with direct impact on water availability and quality. Given both sectors heavily rely on each other the failures of one are likely to result in a flow of failures on the other. A lack of integrated planning between these sectors not only undermines efforts to create sustainable energy and water systems, but also underpins environmental injustices. There is limited understanding on how to tackle these complex interactions in the context of developing countries. Approaches to WE scarcities and stress usually consider supply side solutions, such as more power plants and dams, water transfers and flood levees. Soft-path solutions in benefit of sustainability, with lower consumption and fewer impacts on the environment with decentralised systems, more solar photovoltaic and demand management can only be considered through joint planning processes. Local and regional decision-making for WE has the potential to raise opportunities for adaptation to global change processes and the sustainability and climate agendas. This paper will advance the notion that WE are coupled at multiple scales to support integration of planning at basin level and help move the W-E nexus beyond an input-output relationship.

\section{METHODS}

An analytical tool has been developed (Figure 1) to analyse cost trends resulting from the regulatory framework that concentrates risks on big hydroelectric projects, but increasingly relies on thermal power due to multiple hydrological and non-hydrological factors that impact on reservoir levels and hydro contribution to supply. A variable economic value is allocated to the energy produced by hydropower plants, so that it is lowest when reservoirs are full and higher when there are reductions of the stored water in reservoirs. This way, the electricity system's operation planning and definition of prices are directly influenced by levels of stored water under reservoirs and hydropower contribution to supply. 


\section{HYDROLOGICAL RISKS}

- Significant alteration on precipitation levels

- Recurrent and prolonged droughts and floods

- Low water inflow in major reservoirs

- Rising temperatures that results in higher

levels of evaporation

- Salt water intrusion in coastal region

\section{NON-HYDROLOGICAL RISKS}

- Chronic delays on delivery of new generation plants and transmission lines

- Non-successful tenders for the construction of new plants

- Mismatch between planning and operations

- Structural changes, such as increasing

intermittent sources and run-off-river plants

- Regulatory issues

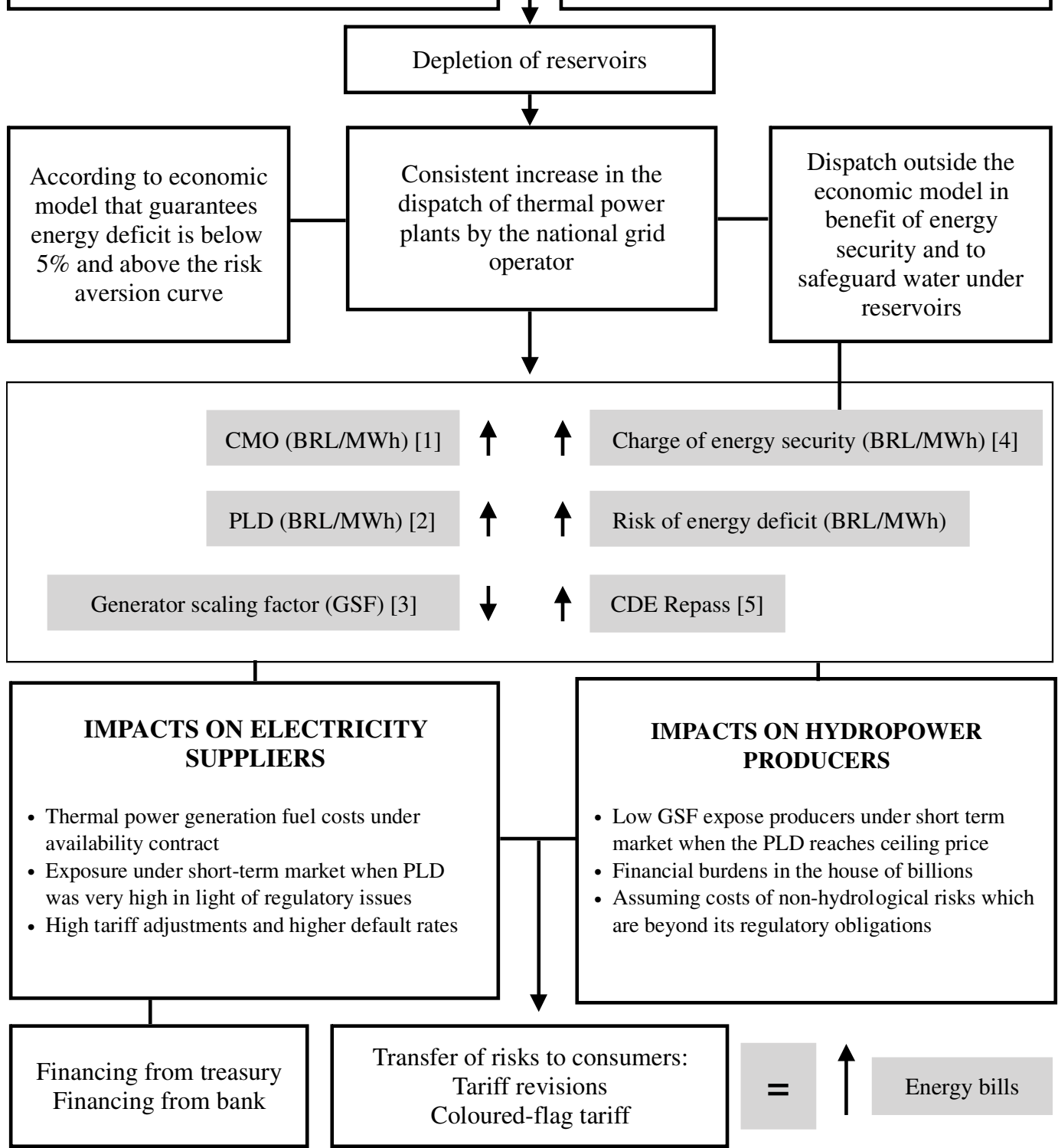

[1] CMO $($ BRL/MWh $)=$ Marginal operational costs of the electricity system, calculated for each subsystem

[2] PLD $(B R L / M W h)=$ Settlement price of short-term market for electricity trade calculated in line with the CMO, but limited to a maximum and minimum amount set by the energy regulator

[3] GSF = Ratio between generation and physical guarantee of hydropower plants needs to be equal to 1, or 100\%, or else it results in negative GSF and exposure of producers under the short-term market when PLD is also increasing

[4] ESS $(\mathrm{BRL} / \mathrm{MWh})=$ Energy services charge created to cover the costs of dispatches of thermal power plants outside the economic model

[5] $\mathrm{CDE}=\mathrm{A}$ sectoral fund that serves to cover costs of several electricity policies

Figure 1. Analytical tool for W-E nexus operational cost trends

Considering the hydrological and non-hydrological factors that impact on the levels of reservoirs and hydro generation, more thermal and less hydro generation results in 
higher marginal operational costs (CMO). The CMO is calculated according to hydrological conditions, energy demand, fuel costs, dispatch of new generation plants and transmission lines, which altogether determine the costs of production by the model and the optimal dispatch of hydro-generation and thermal power under each electricity subsystem. In general terms, the CMO rises in relation to the fuel costs of the most representative thermal plant brought online on a given period. It is assumed that hydropower is always the most economical source of electricity. However, this assumption leads to higher future costs due to higher risks of energy deficit. The security of the system depends on water storage, which means more thermal power is required to help safeguard water and secure supply. Risk aversion mechanisms can enhance energy security of supply and help guarantee minimum levels of water are stored under reservoirs [31]. These mechanisms establish new criteria for calculating the CMO and the frequency of dispatches of thermal power plants, so the model can capture better the uncertainties of water inflows and future costs. Under the economic rationale, the higher the CMO, the higher the risk of energy deficit, the higher the PLD and more funds from regulatory charges are necessary to cover operational costs.

Dispatches of thermal power plants can also happen outside the economic model in benefit of energy security and because of electric restriction. However, additional funds from regulatory charges, such as energy services charges (ESS) are necessary to cover the additional costs of these dispatches outside the economic model. In light of hydrological and non-hydrological factors (Figure 1), thermal plants are increasingly brought online, according to their costs of production, from the lowest to highest, while hydro generation gradually decreases its contribution to supply. This impacts negatively on multiple stakeholders, including producers and suppliers of electricity due to increased cost trends, which also impacts consumers. For example, hydropower producers struggle with non-voluntary exposure under the short-term market when the PLD is very high, which result in financial burdens related to Generation Scaling Factor (GSF) (Figure 1). On the other hand, suppliers struggle with fuel cost payments related to thermal power plant generation, which raise their short-term costs associated with electricity (Figure 1). The transferring of costs to consumers lead to higher energy bills and potential energy poverty.

\section{ANALYSIS AND RESULTS - BRAZIL AS A CASE STUDY}

Brazil has a long history of large-scale hydroelectric power generation, which is one of the well-known dimensions of the nexus between WE. Water is the backbone of the Brazilian energy sector and according to its expansion plans it will continue to serve this purpose. The 10-year plan for energy shows that the total installed capacity of electricity is expected to increase from $132.9 \mathrm{GW}$ to $206.4 \mathrm{GW}$ between 2015 and 2024 [32]. Hydropower projects should contribute with 28.349 MW, representing one third of all investments [32]. The energy sector has historically acted as one the principal management agents and users of water, with damns mainly developed for the exclusive use of hydropower and to assure regular flows of water in seasonal rivers. The installed capacity of hydroelectric generation grew from 13,724 MW in 1974 to $96,925 \mathrm{MW}$ in 2016 [33]. Followed by thermal power plants, which grew from 4,409 MW in 1974 to 41,275 MW in 2016 [33]. Thermal power was mainly developed to serve as back-up of the electricity system and enhance security of supply, but it is increasingly serving to complement base load. Between 2004 and 2016 the total installed capacity of thermal power doubled from 19,556 MW to 41,275 MW (Figure 2). Despite the growing installed capacity of hydropower for the same period, its contribution to supply decreased from $74 \%$ in 2004 to $68 \%$ in 2016 [33] due to hydrological and non-hydrological factors made evident in Figure 1. 


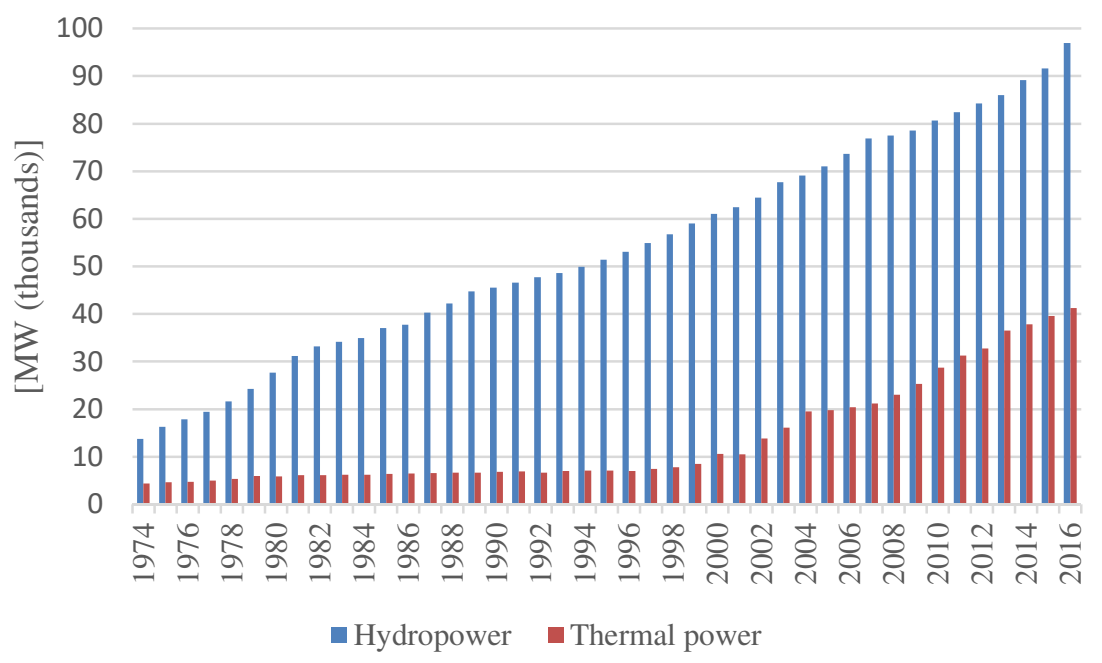

Figure 2. Hydropower and thermal power installed capacity in Brazil between 1974-2016

According to the national legislation [34], the choice of electricity source should be based on economic merit and energy security, whereby the aim of the system is to service demand at any given time, at the lowest possible cost, guaranteeing risks of energy deficit be kept equal or below 5\% under each individual subsystem: North (N), Northeast (NE), Centre-Southeast (C-SE) and South (S) (Figure 3).

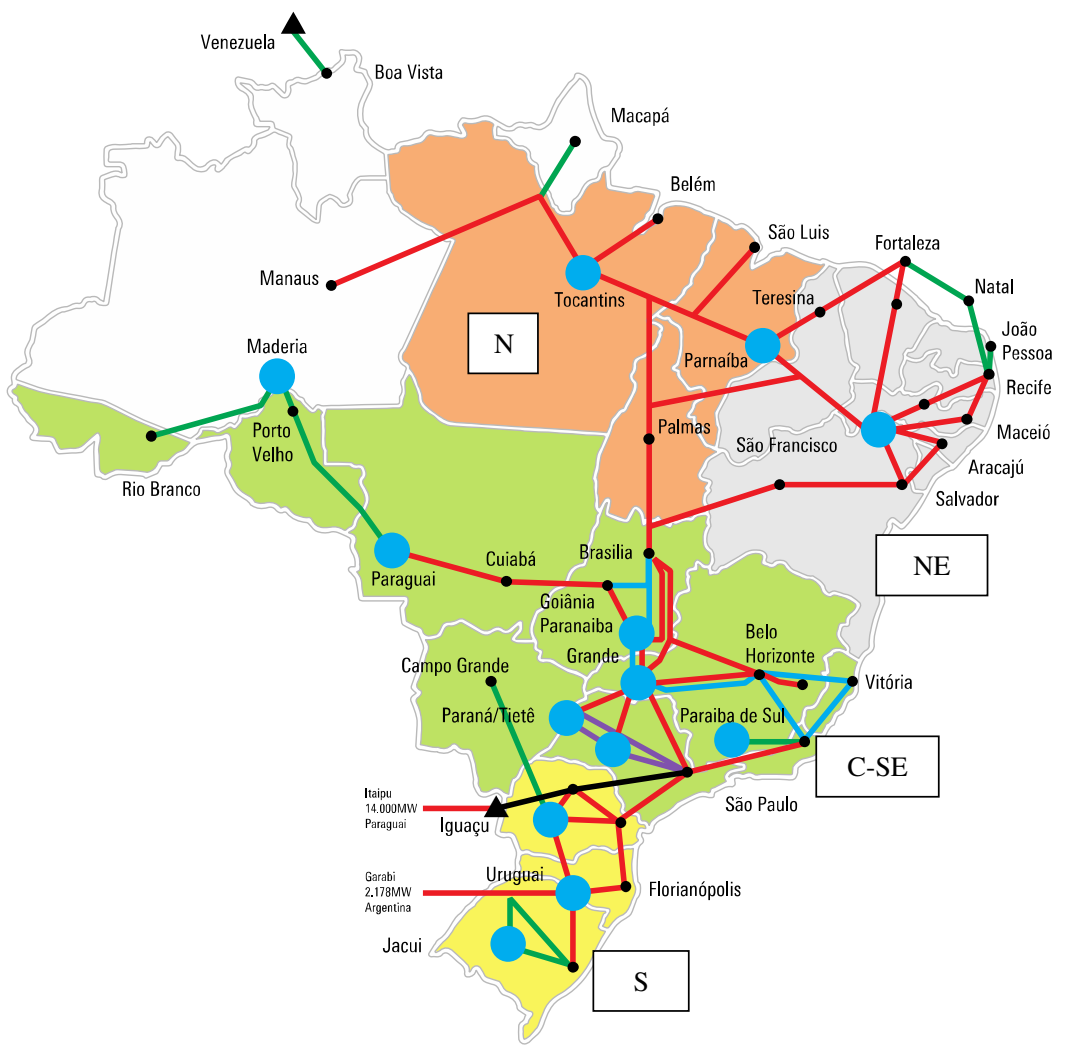

Figure 3. Four subsystems of the electricity sector (adapted after [35])

The risk of energy deficit is a percentage obtained from hydrological simulations that result in a marginal operational cost (CMO) equal to or above BRL 4,650.00/MWh and requires rationing of electricity [36]. The higher the $\mathrm{CMO}$, the higher the risks of energy deficit and the risks of energy rationing. Before 2017, the risk of energy deficit was split into four tiers, updated every year. In 2015 the tiers varied between CMO's of 
BRL 1,420.34/MWh and BRL 7,276.40/MWh [37] (Table 1). Each tier required different percentages of load reduction through electricity rationing (Table 1).

Table 1. Energy deficit cost levels and load reductions for 2015 [37]

\begin{tabular}{ccc}
\hline Tiers & Deficit cost [BRL/MWh] & Levels [\% of Load Reduction (LR)] \\
\hline 1 & $1,420.34$ & $0 \%$ LR $\leq 5 \%$ \\
2 & $3,064.15$ & $5 \%$ LR $\leq 10 \%$ \\
3 & $6,403.81$ & $10 \%$ LR $\leq 20 \%$ \\
4 & $7,276.40$ & LR $>20 \%$ \\
\hline
\end{tabular}

Even though in January 2015 the CMO reached levels beyond the first tier under the $\mathrm{NE}$ and C-SE subsystems, the government did not implement any rationing measures, which led to further depletion of reservoirs and increased use of thermal power generation (including outside the economic model). It has been assumed that all existing thermal power plants were needed for uninterrupted months in the severe drought period of 2014-15, which contributed to the rise of the CMO. For example, during the months of April 2015 to August 2015, thermal plants with variable unitary cost of over BRL 1,100/MWh were brought online [38]. Consequently, there are many still growing economic, social and environmental burdens to all stakeholders. For instance, when thermal plants with variable unitary costs $\leq$ BRL 422.56/MWh are dispatched, the red flag applies, which can result in additional costs to the energy bill of BRL 3.00 for each $100 \mathrm{kWh}$ of energy consumption (BRL $422.56 \geq \mathrm{BRL} 610 \mathrm{MWh}$ ), or BRL 5.00 if thermal power plants with variable unitary costs above BRL 610/MWh are needed [38]. Plants with variable unitary costs equal to or above BRL 211.28/MWh and below BRL 422.56/MWh require the application of the yellow flag and there is an additional BRL 1.00 for each $100 \mathrm{kWh}$ of consumption [38]. There is no addition to the energy bill when thermal power plants brought online have variable unitary costs below 211.28/MWh (green flag tariff). The red flag was applied throughout the entire year of 2015 [38]. For the baseline year (2015), the coloured-flag tariffs were applied individually for each subsystem, according to the sum of the CMO and energy services charge [39]. Then, the flags were defined for the whole system, based on the highest Variable Unit Cost (CVU) of the last thermal power plant dispatched according to the economic rationale or in benefit of energy security [38]. The funds collected through the coloured flag tariffs are centralised under a common account and are supposed to cover the following costs [40]:

- Power purchase agreements of availability of energy under the regulated market (thermal power generation fuel costs);

- Results of short-term market;

- Hydrological risk of hydropower plants under quota-regime (related to forcefully reduced tariffs by government);

- Energy service charge connected to thermal dispatches outside the economic model;

- Hydrological risks of hydropower producers under the regulated market.

There is a deficit in this account, because the amounts collected thus far have not been sufficient to cover all the accumulating costs. In October 2017 the deficit reached around BRL 4.36 billion, which will need to be compensated in the near future through coloured-flag tariffs, annual tariff revisions and tariff readjustments that happen every four years [41]. This indicates energy bills will continue to rise exponentially.

The two most critical energy subsystems are the Centre-Southeast and the Northeast. Both represent risks, because together they are responsible for nearly $90 \%$ of total storage capacity of the Brazilian electricity system [42]. They have the majority of the large-scale 
reservoirs and the highest concentration of people, agrobusiness and industrial activities. Despite the growing contribution of thermal source to safeguard water under both subsystems, it was also necessary for major hydropower plants to reduce levels of water discharges below the minimum set under exiting permits to avoid major dams from drying out. For example, the three major hydropower developments - Sobradinho, Três Marias and Luiz Gonzaga - which hold $96.6 \%$ of total storage capacity of electricity of the Northeast subsystem have reduced significantly their discharge levels (Figure 4). They are located under the São Francisco watershed in the largest river starting and finishing within Brazil that is facing the worst reductions on water flow in recent history. Whereas the São Francisco river had an average discharge of $2,000 \mathrm{~m}^{3} / \mathrm{s}$, it currently stands at $550 \mathrm{~m}^{3} / \mathrm{s}$ [43]. Energy is an important water user, with installed hydropower capacity of 10.708 MW (12\% of Brazil's total capacity) [43]. Sobradinho holds $58.25 \%$ of the total energy storage capacity and plays a fundamental role on the management of water for its multiple uses and energy security [43]. The first authorization to reduce the minimum water discharge levels for Sobradinho from $1,300 \mathrm{~m}^{3} / \mathrm{s}$ to $1,100 \mathrm{~m}^{3} / \mathrm{s}$ was in 2013 [44]. Further reductions authorised by the competent regulatory and environmental bodies decreased the discharge levels to $900 \mathrm{~m}^{3} / \mathrm{s}$ (2015) [45], $800 \mathrm{~m}^{3} / \mathrm{s}$ (2016) [46], $700 \mathrm{~m}^{3} / \mathrm{s}$ (2016) [47] and 550/523 $\mathrm{m}^{3} / \mathrm{s} \mathrm{(2017)} \mathrm{[48].} \mathrm{This} \mathrm{has} \mathrm{impacted} \mathrm{on} \mathrm{the} \mathrm{generation}$ characteristics of the Northeast subsystem, imports from other subsystems, energy costs and on water quality, quantity and multiple water users. Figure 5 shows the reductions in hydro generation by the main hydropower plants located under the São Francisco basin: Sobradinho, Xingó, Luiz Gonzaga and Três Marias.

Figure 6 shows the consequent rises in thermal power, the marginal operational costs (CMO) and the PLD for the NE subsystem. The higher the CMO the higher the PLD, but whereas there are no limits to how much the CMO can rise, the PLD is limited by regulatory cap that is established on early basis by energy regulatory agency (Figure 6). The PLD is one of the key factors that determines the application of the coloured-flag tariffs. The steep fall of the PLD in January 2015 (despite CMO being high) shown under Figure 6 is because the cap price of PLD was changed by energy regulator. Moreover, Figure 6 shows that increases in wind power generation in 2016 was one of the main factors that helped decrease the marginal operational costs and consequently the PLD in the NE subsystem.

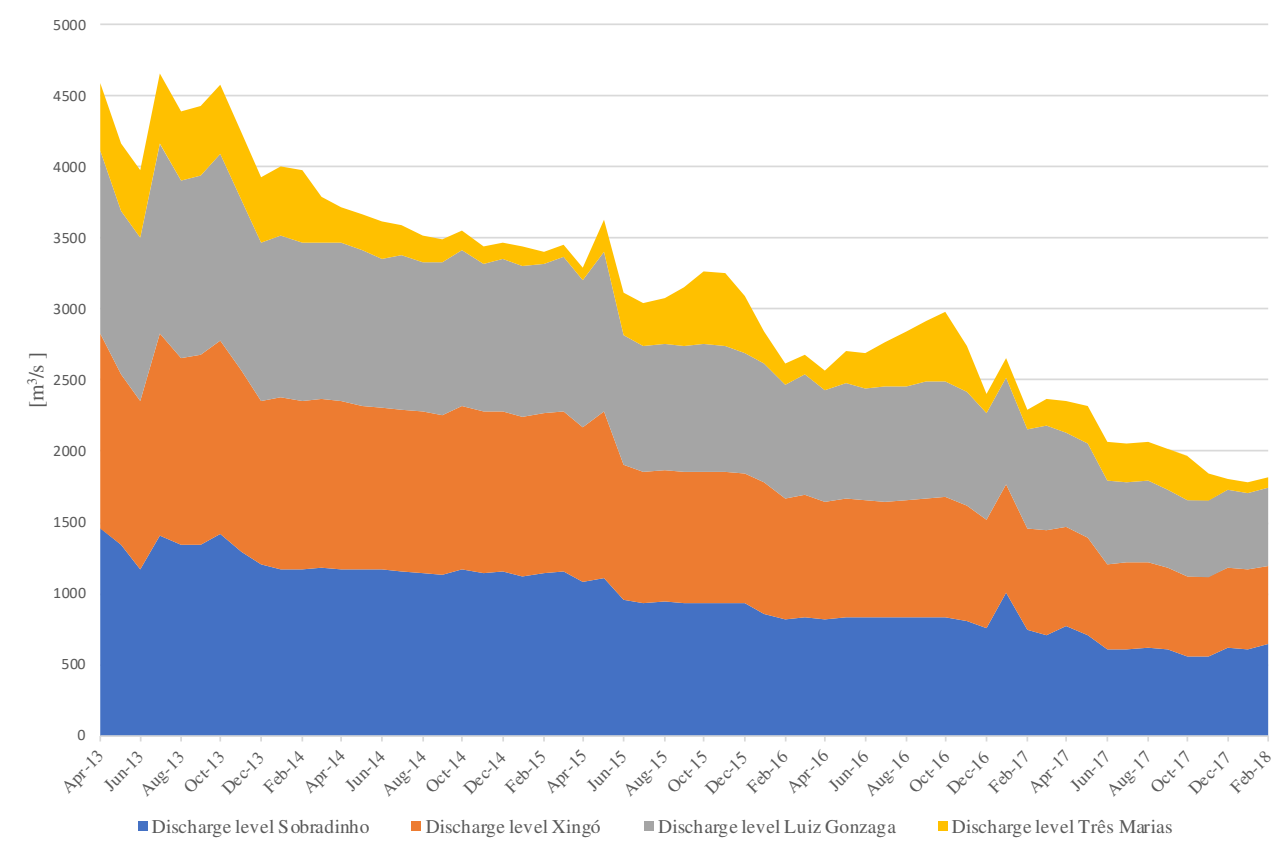

Figure 4. Reduction in discharge levels of main hydropower plants of NE subsystem 


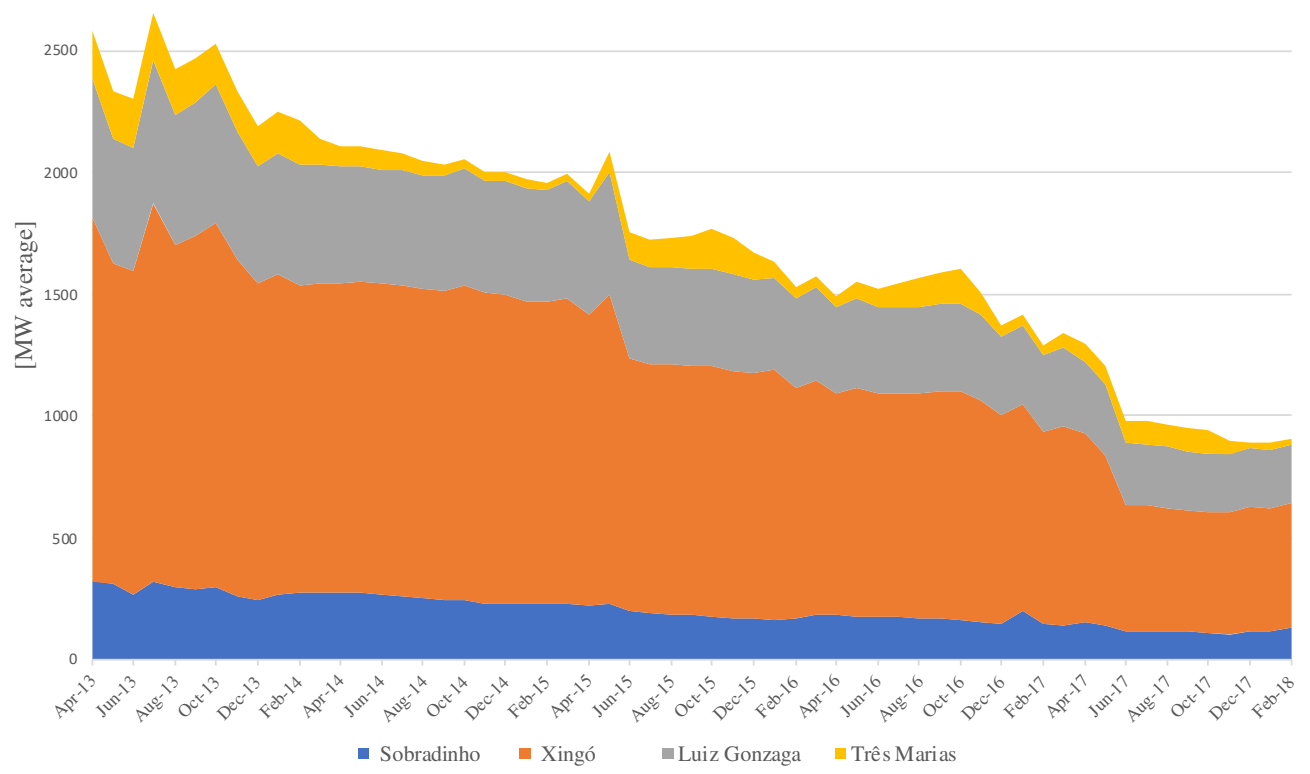

Figure 5. Hydro generation reductions by main hydropower plants of NE subsystem

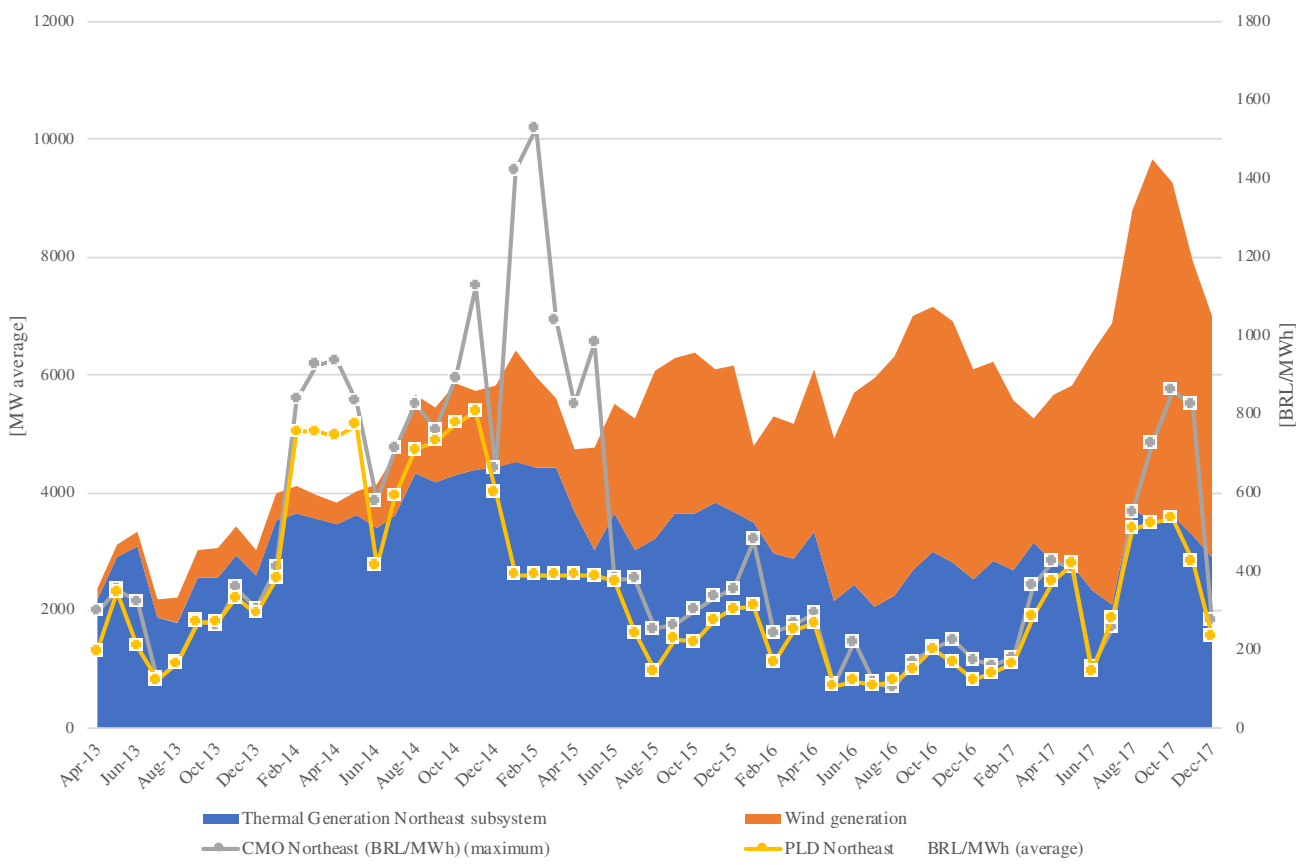

Figure 6. Rises in thermal power, marginal operational costs and the PLD for the NE subsystem

To some extent, a similar situation occurred under the Centre-Southeast subsystem (C-SE). However, different from NE where the energy storage capacity is mainly under one critical watershed (São Francisco), the C-SE has its main reservoirs under eight different basins: Paraíba do Sul, Tocantins, Grande, Paraná, Paranaiba, Paranapanema, São Francisco and Tietê [42]. The most critical being the Paraíba do Sul and Tocantins, where it has also been necessary to reduce hydropower's minimum discharge below environmental permit levels. The Paraíba do Sul holds $3.2 \%$ of energy storage of the C-SE subsystem [42] and is located between the biggest industrial and populational poles (São Paulo, Minas Gerais and Rio de Janeiro). Hydropower plants have reduced discharge levels from $30 \mathrm{~m}^{3} / \mathrm{s}$ to $7 \mathrm{~m}^{3} / \mathrm{s}$ (Paraibuna), from $40 \mathrm{~m}^{3} / \mathrm{s}$ to $10 \mathrm{~m}^{3} / \mathrm{s}$ (Santa Branca), from $80 \mathrm{~m}^{3} / \mathrm{s}$ to $60 \mathrm{~m}^{3} / \mathrm{s}$ (Funil), and from $10 \mathrm{~m}^{3} / \mathrm{s}$ to $4 \mathrm{~m}^{3} / \mathrm{s}$ (Jaguari) [49]. 
Nonetheless, these developments are supposed to guarantee adequate water flow for the operation of Santa Cecília reservoir that secures water supply to Rio de Janeiro. Under the Tocantins watershed, the hydropower Serra da Mesa that holds $17.35 \%$ of the total energy storage capacity of C-SE has reduced its discharge level from $320 \mathrm{~m}^{3} / \mathrm{s}$ to $100 \mathrm{~m}^{3} / \mathrm{s}$ [50]. Despite reductions in hydro generation by these and other hydropower plants under the C-SE electricity subsystem, it faces a different situation than NE subsystem. Figure 7 shows the hydro generation for the NE subsystem, while Figure 8 has the hydro generation for the C-SE between 2013-2017. Furthermore, Figure 9 shows the rises in thermal power and increases in the marginal operational costs (CMO) and the PLD for the C-SE subsystem.

(MW Average)

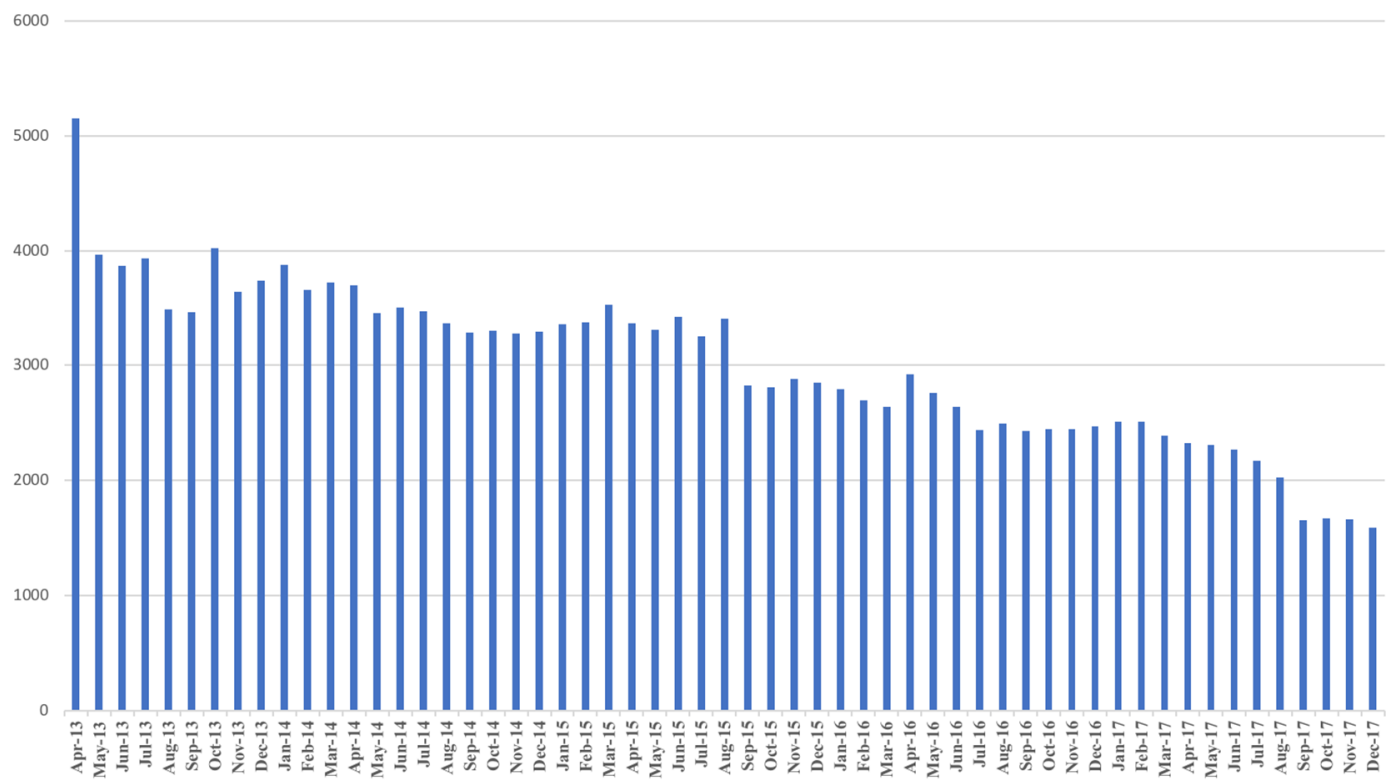

Figure 7. Hydro generation NE subsystem

(MW average)

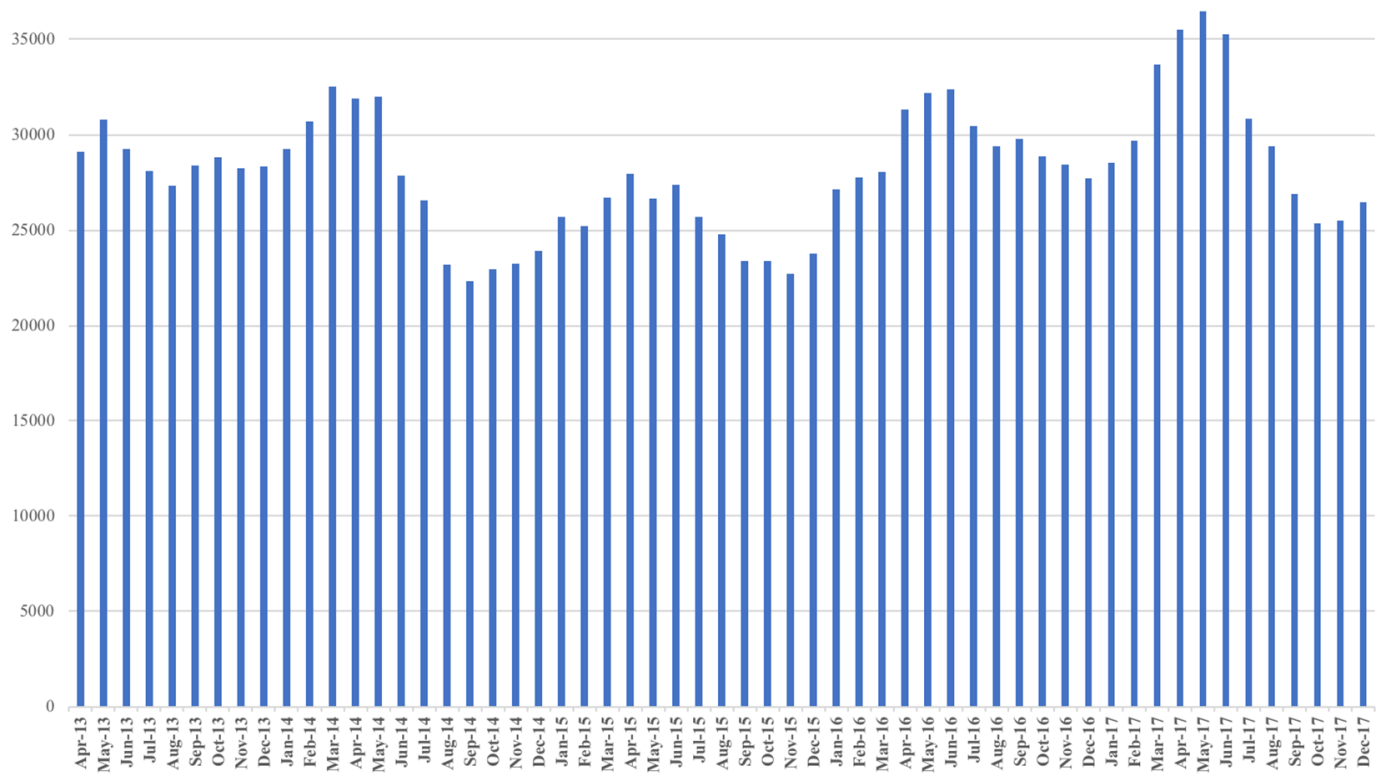

Figure 8. Hydro generation C-SE subsystem 


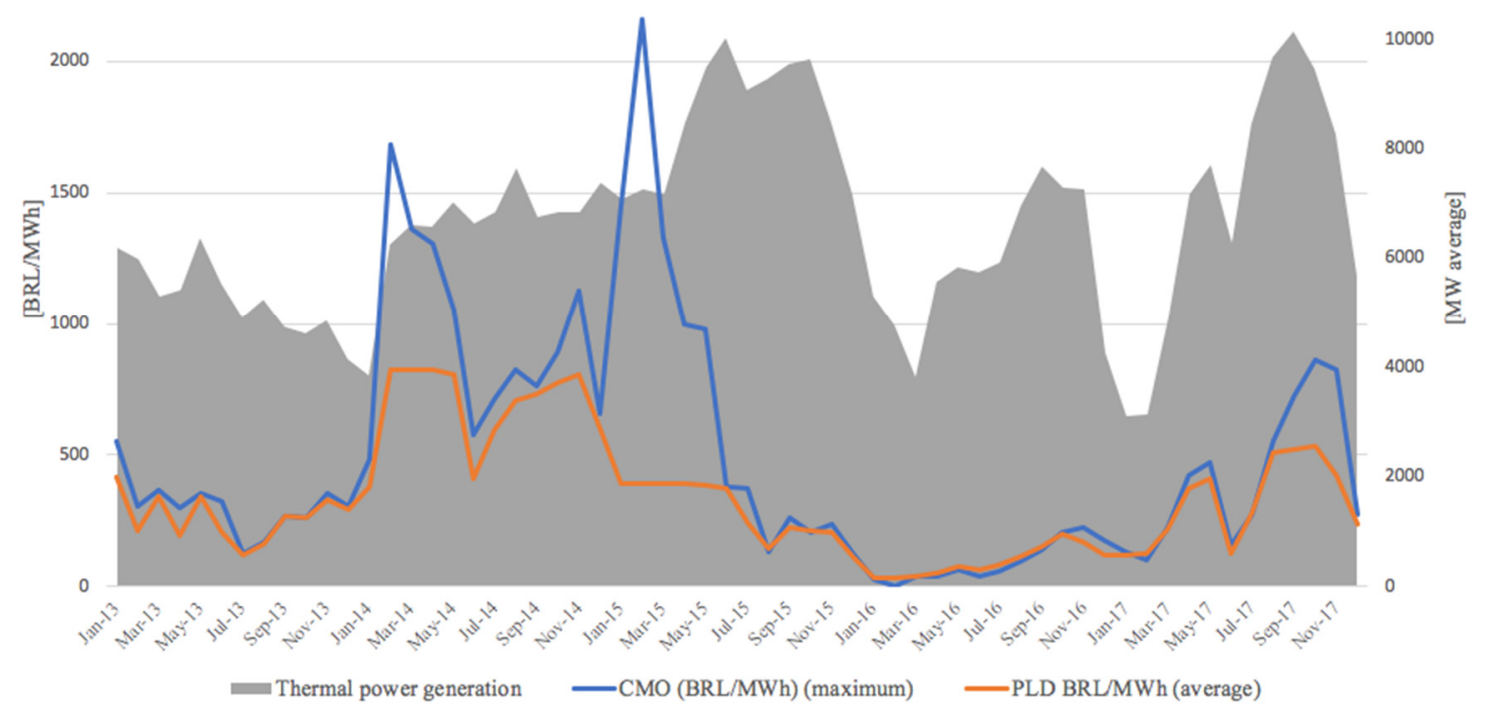

Figure 9. Rising thermal power, marginal operational costs and PLD for the C-SE subsystem

One of the main problems of reductions in hydro generation under both subsystems, which was aggravated by the drought, is that many producers were generating less than their total assured output under the Energy Reallocation Mechanisms (MRE). Consequently, the GSF - which is the percentage of energy that all generators in the MRE produce in relation to the MRE's total guaranteed power output in a given month was constantly below 1, or $100 \%$. The combination of low GSF and high PLD impacted negatively on the financial stability of energy producers. Hydropower producers that were generating less than their guaranteed output under the MRE battle with their repeated and non-voluntary exposure under the short-term market when the PLD was very high, which has led to GSF financial burdens as follows: BRL 2.8 billion (2013), BRL 26.8 billion (2014), BRL 20.0 billion (2015) and BRL 39.7 billion (2017) [38]. Because several non-hydrological factors led to their exposure, such as delays on delivery of new plants and transmission lines, it is considered that producers transfer the risks to consumers under the argument that these costs go beyond their contractual obligations that are limited to risks of hydrological nature. In 2015, the federal government edited a new law that transferred the costs of these risks to the consumers under the regulated energy trade market [51]. These costs are to be covered by the revenues of the coloured-flag tariffs. However, only the hydropower producers under the regulated market for electricity transferred costs to captive consumers of energy suppliers, which includes water services and sanitation providers. The financial burdens of producers under the free market for electricity trade continue to grow and questions are raised about how to remedy such debts that are raising many operational, legal and financial risks. Other costs transferred to consumers are related to the financial burdens assumed by electricity suppliers in light of their exposure under spot market in connection to Provisional Measure 579 of 2012. Electricity suppliers face huge financial burdens related to this political decision that forcefully reduced tariffs [52] but led to their unforeseen exposure under the short-term market when the PLD was very high and resulted in unexpected rise in their electricity costs and obligations, which were not covered by the energy tariffs. To cover these costs the following actions were taken:

- Transferring of funds from the national treasury;

- The chambers for electricity trade entered into a loan agreement in name of the electricity suppliers; 
- Transferring of funds from coloured-flag tariffs;

- Tariff revisions that reached up to $40 \%$ in 2015 [53].

Moreover, when thermal power plants are dispatched, distribution companies should bear variable fuel costs payments and imbalance settlement cost/revenues [54]. In 2014 variable fuel costs reached BRL 17.5 billion, while the combination of fuel costs and imbalance settlement led distributors to a combined turnover of BRL 62 billion in 2014 [54]. The monthly revenues of the coloured-flag tariffs are also used to cover these costs.

The short-term and steep rise of energy bills impacts on the financial stability of electric-intensive sectors such as Water Services and Sanitation (WSS), because electricity represents the highest cost of providers after labour costs [55]. In general, most WSS providers of Brazil struggle with increasing energy bills. For example, the WSS sector reduced its overall energy consumption in 2015, but its total energy costs were $50 \%$ higher due to the high tariff adjustments and the new coloured-flag tariffs [56]. However, WSS providers under the São Francisco struggle not only with rising energy bills, but with reduced water quantity and quality due to reduced river flow, which requires more investments and more energy to source water, in times when energy is the most expensive. The situation is aggravating for WSS providers downstream of hydropower plants that have reduced discharge levels. For example, with reduced river flow, the sea has advanced into the São Francisco riverbed and the WSS provider of Alagoas (CASAL) has been forced to make new investments to capture water, because its old system was affected by salinization and can't be used [57]. On the other hand, CASAL issued in 2016 an acknowledgement of debt in favour of the energy supplier of the state of Alagoas (CEAL) of BRL 250,198,922, which is more than double of the amount of its existing liability towards CEAL in December 2015 [58]. Its energy costs doubled between 2014 and 2015 from BRL 26,356,258 to BRL 58,727,724 [59]. Another example downstream of Sobradinho involves the WSS supplier of the state of Sergipe. In December 2017, its system to capture water that secures water supply to the capital of state Aracaju reached its limit point of pumping suction, which could have resulted in interruptions that would affect approximately one million people [60]. To mitigate the risks two floating pumps from the WSS provider of the state of São Paulo were provided [60]. Its highest costs with electricity were incurred in 2014 (BRL 2,046,293) [61] and 2015 (BRL 2,395,410) [62], which is more than double of the amount of 2017 (BRL 1,011,238) [60]. In the case of the WSS provider of the state of Bahia, its obligations towards the energy supplier were three times higher between 2015 (BRL 1,621,000) [63] and 2016 (BRL 4,560,000) [64]. Other states that compose the São Francisco watershed are Minas Gerais, Pernambuco, Goiás and the Federal District. Apart from Minas Gerais and Pernambuco, all of other states including Alagoas, Sergipe and Bahia have total costs per $\mathrm{m}^{3}$ higher than their average tariffs [56]. This is highly problematic for the rendering of sustainable services and complying with rising energy costs. To universalize supply by 2033 in line with objectives of sanitation policy and planning, more investment on energy efficiency is required. On the other hand, the energy planning is not very detailed about energy requirements to universalise supply and assumes that the growth rate is covered under the growth rate of electricity distribution, water and gas as a whole, which is assumed to be close to the GDP [32]. Moreover, there isn't a stable regulatory framework to attract the investments to promote the required efficiency and expansion of WSS. The challenges are even greater when taking into consideration that municipalities are competent to plan and regulate WSS, but many lack financial, technical and administrative capacities. Under the São Francisco the majority of municipalities have entered into concession agreements with the states, but there are many which are rendering the services directly, or through consortium of municipalities, but lack efficiency and security of supply. Municipalities do not hold water domain, so they only participate of water committees and play a subsidiary role in 
the management of water resources when compared to the national and state governments that have normative and management capacities. This has many implications for better integrated planning, which will be discussed under the next section.

\section{INTEGRATION OF WATER AND ENERGY PLANNINGTO ADVANCE SUSTAINABILITY}

River basins serve multiple and distinct users at different levels exploring it for different purposes, which make it particularly difficult to govern it in a country heterogeneous as Brazil. The complexities are even higher if considering that these resources are also complex natural systems and produce multiple goods and services [65]. Despite energy and water being highly intertwined in Brazil, their governance follows opposing approaches connected to the distinct nature and scale of their activities, institutional set up, different economic rules, varying degrees of liberalization, unbundling and diverse policy and regulatory frameworks. These sectors have gone through several structural transformations along the time and Figure 10 shows the current governance structure for energy and water from national, state and municipal levels, including the watershed level created by law for the management of water resources at its catchment area.

As shown in Figure 10, for water, the same institutional structure that exists at national level for management of national waters is replicated at state level for management of waters under state domain. The double domain of water resources raises many difficulties and controversies connected to the need of aligning national and state's planning and management systems coexisting within a same watershed [66]. At the basin level, federal and state water committees are composed of water users, civil society and public authorities from all levels (national, state and municipal) [67]. The basin committee has normative, deliberative, consultative roles and should establish the mechanisms to implement water charges and develop the basin water plan. For example, under the São Francisco coexists the water management systems of Alagoas, Bahia, Distrito Federal, Goiás, Minas Gerais, Pernambuco, Sergipe and the national government. There are water plans for each state, the national level and basin level. In terms of WSS, there is a national sanitation policy from 2007, but restricted to very general guidelines, because the execution and operation of the activities are under the competence of Municipalities, which sum to more than 500 in São Francisco watershed. Considering that most states under the São Francisco basin count with regional WSS providers, there are challenges that emerge from diverging regulatory and planning approaches of the various municipalities at local scale.

Contrarily, energy is highly centralised under the national government. There are national institutions responsible for electricity policies, planning, regulation, centralised operations and trading. From a policy aspect, the Ministry of Mines and Energy (MME) and the National Council for Energy Policy (CNPE) undertake the activities of the government. The regulation and supervision of the electricity sector, including renewables, is undertaken by ANEEL [68]. The monitoring and evaluation of supply security are under the competence of the National Monitoring Committee of Electricity (CMSE), which was established in 2004 with representatives of all institutions of the energy sector. The National Research Energy Company (EPE) undertakes activities related to planning, while centralised operations are undertaken by the National System Operator (ONS). Finally, the Chamber for Electricity Trade (CCEE) is a non-profit entity regulated and monitored by ANEEL. The rationale behind the energy regulatory framework is that in centralising planning under the national government and acquisition under wholesale market it would secure supply and make feasible bigger projects that would offer cheaper energy by negotiating bigger blocks of energy. This way believed to keep affordable tariffs in place. The problem of this assumption is that price of energy is 
not related to the form of contracting, but to the source. Hydro is the cheapest source, but its unavailability in light of hydrological and non-hydrological factors results in higher energy costs (Figure 1). The regulatory framework allowed for concentrated risks on big projects, with its centralised operational and planning structure promoting systemic overexploitation of reservoirs [69]. On the other hand, the current goals and targets of electricity planning are not linked to overall water demand, or their implications for water allocation and quality. For instance, the decennial energy plan is clear in recognising the advantage of thermal plants because they can be near urban centres and near fuel source, but nowhere does it mention the need to also consider water availability [32].

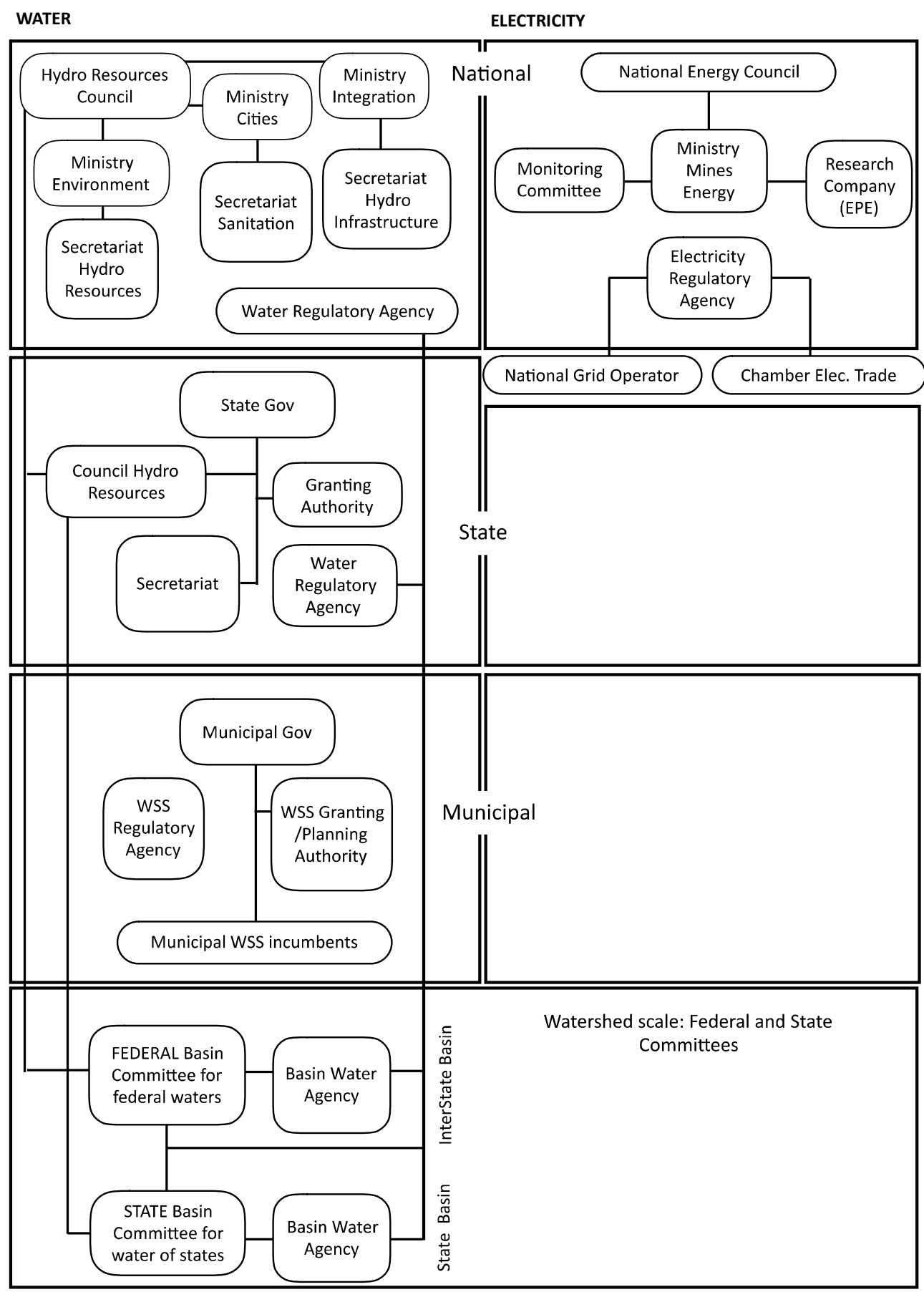

Figure 10. Institutional structure of WE in Brazil

Moreover, there is a disjunction amongst multiple water plans at national, state, interstate and basin level, and between these and other sectoral plans, such as electricity 
plans at national level and multiple sanitation plans at local level. Water plans have different timeframes, overlapping areas of action and diverging priorities. The different time frames and silo approach result in multiple uncoordinated plans with many goals under intersecting areas, which are hard to implement in integrated manner. States have different technical, financial and administrative capacities to develop plans and implement them, so asymmetries are common within shared basins. All of these issues increase the challenges to coordinate and develop the necessary linkages between water plans and other relevant plans of energy, sanitation, land use, development and biodiversity in benefit of sustainability. Considering that securing affordable and universal access to WE increasingly depends on more than one critical infrastructure, the state is challenged to design new cross-regime governance and planning [70]. Solutions to problems need to be formulated and implemented in the context of polycentric, highly complex and interdependent networks of formal and informal actors [71]. Today, hydroelectric producers explore water at national level, subject to centralized regime of electricity sector, while all other non-hydroelectric users are under a decentralised and participative governance regime at the basin level. This leads to situations where one river can potentially be subject to both regimes, following different rationales of each scale and sector, which raises disputes. The development of horizontal cooperative planning structures is key to increase participatory and joint development and use of public intervention instruments [71]. Today, current efforts to mitigate the risks of water scarcity under the São Francisco basin includes a "Critical Events Room" coordinated by the national regulatory agency. It holds online meetings with high frequency between the national grid operator, the electricity producers, environmental bodies, large-scale agrobusiness representatives, water committee representative, state WSS providers and meteorological bodies. The national grid operator for electricity is usually the one responsible for bringing forward the recommendations to reduce water discharge and guaranteeing in connection with National Water Agency of Brazil (ANA) that reservoirs have minimum water levels to safeguard energy security and multiple water uses. Procedural justice issues can be raised, because there are stakeholders at basin level that are left unheard under these emergency-driven discussions of the Critical Events Room. In some ways, the water committee lost its role of serving as forum for discussions between multiple water users. Most WSS providers, which depend on both WE as inputs for the rendering of its services do not participate of the decisions. Although the decisions under the Critical Events Room have been successful in preventing important reservoirs like the Sobradinho from drying out and guaranteeing multiple water uses, the approaches to scarcity usually considers emergency-driven supply side solutions. Soft-path solutions in benefit of sustainability, with fewer impacts to the environment require planning and deliberation processes that consider nexus perspectives and include state and non-state actors of both sectors at initial stages of basin planning. Procedural cross-sectoral collaboration, coordination and networking are required at the planning phase through shared responsibility and shared resources to reduce administrative fragmentation. To help strengthen the basin plan, different water users at basin level should provide long term plans of water requirements, including the energy sector.

For Brazil to advance the Sustainable Development Goal (SDG) targets of improved water efficiency and energy efficiency, the reinforcement of both the energy access and the sustainable water withdrawals targets are necessary. To advance the targets of universal WSS supply, it will be necessary to consider energy efficiency to curb costs of energy, especially in areas where tariffs currently do not cover costs. Advancing the SDG's through nexus thinking in Brazil could support the development of better integrated W-E efficiency programs in which utilities can share knowledge and co-develop programs. Moreover, it could support a more integrated approach not only to 
WE planning, but also to the different policies and plans connected to the goals of WE shown under Table 2 and Table 3. This is key in light of the structure of the set of SDG goals, which have implication for policy integration and coherence across areas. Nevertheless, all efforts to plan these sectors in a more integrated way will face the challenges of creating rules that make sense for the particular social, biophysical, and institutional context in which they exist [72]. Considering that water is managed at basin level, the basin plans are one of the main instruments of the national water policy that needs to be strengthened. The state has an important role as the producer of legislation and granter of permissions [70]. Likewise, as the setter of recommendations and sanctions for reducing negative impacts on the environment, economy and people [70]. A range of non-state actors such as consumers, owners of infrastructure assets, private infrastructure investors and insurers should also be involved in the governance of infrastructure interdependencies [71]. This way, greater integration is also dependent on state and non-state actor's involvement, both during policy and planning formulation and implementation. They should collaborate, make joint-decision and resolve conflicts [73]. There are several instances of public participation in Brazil such as councils, water committees, public consultations, and public hearings, but the effectiveness of these bodies is questioned, especially in light of studies that have identified capture by interest group. Considering there are no general standards with regards to the processes involved in public participation, each sector establishes its own structures and ways [74]. This way, arenas for public participation have been implemented in disparate ways, with little articulation, which can be seen as an obstacle for the promotion better integrated planning that counts with participation of users in the formulation, execution and monitoring of issues that crosscut water and energy.

Table 2. Energy SDG targets and related policies in Brazil

\begin{tabular}{l} 
Energy SDG targets \\
\hline SDG7.1 By 2030, ensure universal access to \\
affordable, reliable and modern energy services
\end{tabular}
SDG7.2 By 2030, increase substantially the share of renewable energy in the global energy $\operatorname{mix}$

SDG7.3 By 2030, double the global rate of improvement in energy efficiency

SDG7.a By 2030, enhance international cooperation to facilitate access to clean energy research and technology, including renewable energy, energy efficiency and advanced and cleaner fossil-fuel technology, and promote investment in energy infrastructure and clean energy technology

SDG7.b By 2030 expand infrastructure and upgrade technology for supplying modern and sustainable energy services for all
Proposed indicators [75]

(T1 $1_{[2]}, \mathrm{T} 2_{[3]}, \mathrm{T} 3_{[4]}$ also applicable to Table 2)

7.1.1 Proportion of population with access to electricity [T1]

7.1.2 Proportion of population with primary reliance on clean fuels and technology [T2]

7.2.1 Renewable energy share in the total final energy consumption [T1]

7.3.1 Energy intensity measured in terms of primary energy and GDP [T1]

7.a.1 Mobilized amount of United States dollars per year starting in 2020 accountable towards the USD 100 billion commitment [T3]

7.b.1 Investments in energy efficiency as a percentage of GDP and the amount of foreign direct investment in financial transfer for infrastructure and technology to sustainable development services [T3]
National Energy Policy [76]

Related policies

National Energy Policy [76]

\author{
National Policy on \\ Conservation and Rational \\ Use of Energy [77]
}

National Energy Policy [76], Environmental Policy [78], Conservation and Rational Use of Energy [77]

National Energy Policy [76]

[2] T1 - A first tier for which an established methodology exists and data are already widely available

[3] T2 - A second tier for which a methodology has been established but for which data are not easily available

[4] T3 - A third tier for which an internationally agreed methodology has not yet been developed

[5] SDG 7 proposes ensure access to affordable, reliable, sustainable and modern energy for all 
Table 3. Water SDG targets and related policies in Brazil

\section{Water SDG targets}

SDG6.1 By 2030, achieve universal and equitable access to safe and affordable drinking water for all

SDG6.2 By 2030, achieve access to adequate and equitable sanitation and hygiene for all and end open defecation, paying special attention to the needs of women and girls and those in vulnerable situations

SDG6.3 By 2030, improve water quality by reducing pollution, eliminating dumping and minimizing release of hazardous chemicals and materials,

halving the proportion of untreated wastewater and substantially increasing recycling and safe reuse globally

SDG6.4 By 2030, substantially increase water-use efficiency across all sectors and ensure sustainable withdrawals and supply of freshwater to address water scarcity and substantially reduce the number of people suffering from water scarcity

SDG6.5 By 2030, implement integrated water resources management at all levels, including through transboundary cooperation as appropriate

SDG6.6 By 2020, protect and restore water-related ecosystems, including mountains, forests, wetlands, rivers, aquifers and lakes

SDG6.B Support and strengthen the participation of local communities for improving water and sanitation management
Proposed indicators global level [60]

Related policies

6.1.1 Percentage of population using safely managed water services, by urban/rural [T1]

6.2.1 Percentage of population using safely managed sanitation services, by urban/rural [T1]

National Water Policy [67]

Sanitation services for all set under art, $2^{\text {nd }}$ of Law 11.445 [79]

6.3.1 Percentage of wastewater flows treated to national standards [T3]

6.3.2. Proportion of bodies of water with good ambient and water quality [T3]

National Solid Waste Policy [80] and National Environmental Policy [78]

6.4.1 Change in water-use efficiency over time [T3]

6.4.2 Level of water stress: freshwater National Water Policy [67] withdrawal as a proportion of available freshwater resources [T1]

6.5.1 Degree of integrated water resources management implementation 0-100) [T1]

6.5.2 Proportion of transboundary basin area with an operational arrangement for water cooperation [T3]

6.6.1 Change in the extent of water-related ecosystems over time [T3]

6.B.1 Proportion of local administrative units with established and operational policies and procedures for participation of local communities [T1]
National Water Policy [67]

Solid Waste Policy [80], Environmental Policy [78]

National Policy for Public participation [81], National Water Policy [67]

\section{CONCLUSIONS}

The interlinkages between WE made evident under the analytical tool depicts a nexus beyond an input and output relationship in Brazil to consider some of the operational aspects of their relationship. For example, having less water availability for hydropower generation due to hydrological and non-hydrological factors has led to increases in thermal power, including outside the economic model and resulted in higher marginal operational costs for the electricity system. In very general terms, it has become more expensive to produce electricity and safeguard water under reservoirs. This is problematic for electric-intensive sectors like WSS that doubled its costs with electricity in a years' time. The relevant connection between the water sector and energy is not so much about the quantity of energy required to render WSS, but the rising costs of this energy, which in some cases represents more than $60 \%$ of the total costs of WSS providers. Connected to high levels of inefficiency that translate into energy and water losses, it does not support advances to the SDG 6 (water). WSS not only face higher energy bills, but in many cases face lower water quantity and quality for the rendering of the services. Despite the rises in thermal generation and other sources, such as wind in the Northeast subsystem to help safeguard water under reservoirs, it has also been necessary to reduce water discharge levels of major hydropower plants of Brazil to guarantee multiple water uses and energy security. This is problematic for WE intensive sectors like WSS, because they need more energy to source water from other basins or from deeper underground levels in times when energy is the most expensive. On one hand, the energy 
sector's high reliance on water increases its vulnerability to competing uses of water and raises many financial risks. While on the other hand, the water sector's exclusive reliance on a centralised energy sector raises its vulnerabilities connected to the regulatory framework of energy that concentrated all the risks on big hydropower projects and has no plan B.

The challenges are even greater when taking into consideration that water is supposed to be managed at its catchment area by basin committees formed by all scales (national, state and municipalities), water users, such as energy users and irrigators, NGO's and civil society, while WSS is under the competence of municipalities and energy is under the exclusive competence of the national government. This means there are state, national and basin water plans, while there are municipal WSS plans and national energy plans, all of which have very little coordination and do not incorporate important aspects of one in the other. For example, the basin plans do not include important aspects of the energy plans. Brazil's sectorized and fragmented planning does not serve well the purpose of the 2030 Agenda. Traditional decision-making, planning and regulatory frameworks and policies are mainly restricted to sectoral boundaries. Consequently, it is key to develop mechanisms to combine the planning of both towards certain common objectives, so that the physical, geographical, institutional, financial and decision-making interdependencies can contribute to long-term ecological sustainability, security of supply and affordable tariffs. Strengthening the planning at basin level will be key increase public participation and to control socially induced scarcities, degradation of environmental assets and the loss of adaptive capacity to respond to future challenges.

\section{ACKNOWLEDGEMENT}

This study is funded by the Brazilian National Council for Scientific and Technological Development (CNPQ). We acknowledge this funding with gratitude.

\section{REFERENCES}

1. Rio Carrillo, A. M. and Frei, C., Water: A Key Resource in Energy Production, Energy Policy, Vol. 37, No. 11, pp 4303-4312, 2009, https://doi.org/10.1016/j.enpol.2009.05.074

2. Senger, M. and Spataru, C., Water-Energy-Land Nexus - Modelling Long-term Scenarios for Brazil, $9^{\text {th }}$ IEEE European Modelling Symposium on Mathematical and Computer Simulation Madrid, IEEE Computer Society, Madrid, Spain, 2015, https://doi.org/10.1109/EMS.2015.47

3. Energy Research Company (EPE), National Energy Balance 2017: Base Year 2016 (in Portuguese), https://ben.epe.gov.br/BENRelatorioFinal.aspx?anoColeta=2017\& anoFimColeta=2016, [Accessed: 03-June-2018]

4. Sovacool, B. K. and Sovacool, K. E., Identifying Future Electricity - Water Trade-offs in the United States, Energy Policy, Vol. 37, No. 7, pp 2763-2773, 2009, https://doi.org/10.1016/j.enpol.2009.03.012

5. Sovacool, B. K. and Rao, A., Managing the Electricity-water Nexus in China, France, India and the United States (Climate, Energy and Water: Managing Trade-offs, Seizing Opportunities) (Pittock, J., Hussey, K. and Dovers, S., eds.), pp 155-171, Cambridge University Press, Cambridge, United Kingdom, 2015, https://doi.org/10.1017/CB09781139248792.010

6. Kanter, J., Climate Change Puts Nuclear Energy into Hot Water, New York Times, 2007, https://www.nytimes.com/2007/05/20/health/20iht-nuke.1.5788480.html, [Accessed: 03-June-2018]

7. United Nations Environmental Programme (UNEP), Impacts of Summer 2003 Heat Wave in Europe, www.grid.unep.ch/products/3_Reports/ew_heat_wave.en.pdf, [Accessed: 15-August-2018] 
8. Carter, N. T., Energy's Water Demand: Trends, Vulnerabilities and Management, Congressional Research Service, Washington, USA, 2010, https://fas.org/sgp/crs/misc/R41507.pdf, [Accessed: 10-February-2015]

9. Electric Power Research Institute (EPRI), Comparisons of Alternate Cooling Technologies for US Power Plants, Economic, Environmental and Other Trade-offs, USA, 2004, https://www.epri.com/\#/pages/product/000000000001005358/?lang=en, [Accessed: 05-June-2017]

10. Gerbens-Leenes, P. W., Hoekstra, A. Y. and Van der Meer, Th. H., The Water Footprint of Energy from Biomass: A Quantitative Assessment and Consequences of an Increasing Share of Bioenergy in Energy Supply, Ecological Economics, Vol. 68, No. 4, pp 1052-1060, 2009, https://doi.org/10.1016/j.ecolecon.2008.07.013

11. Wang, L., Sustainable Bioenergy Production, CRC Press, Boca Raton, Florida, USA, 2014, https://www.taylorfrancis.com/books/e/9781466505568, [Accessed: 05-June-2017]

12. Semertzidis, T., Spataru, C. and Bleischwitz, R., Cross-sectional Integration of the Water-energy Nexus in Brazil, Journal of Sustainable Development of Energy, Water and Environment Systems, Vol. 6, No. 1, pp 114-128, 2018, https://doi.org/10.13044/j.sdewes.d5.0169

13. Watson, R. and Rai, N., Governance Interdependencies Between the Water \& Electricity Sectors, Working Paper Series of Infrastructure Transitions Research Consortium, 2013, https://itrc.ouce.ox.ac.uk/wp-content/PDFs/Water-Energy-Casestudy-for-publication-final.pdf, [Accessed: 05-June-2017]

14. World Resources Institute (WRI), Aqueduct Water Risk Atlas and Global Water Plant Database, http://www.wri.org/resources/maps/aqueduct-water-risk-atlas, [Accessed: 03-March-2018]

15. World Energy Council (WEC), Water for Energy, 2010, https://www.worldenergy.org/wp-content/uploads/2012/10/PUB_Water_For_Energ y_2010_WEC.pdf, [Accessed: 03-January-2018]

16. Siddiqi, A. and Anadon, L. D., The Water-energy Nexus in the Middle East and North Africa, Energy Policy, Vol. 39, No. 8, pp 4529-4540, 2011, https://doi.org/10.1016/j.enpol.2011.04.023

17. Pittock, J., Hussey, K. and McGlennon, S., Australian Climate, Energy and Water Policies: Conflicts and Synergies, Australian Geographer, Vol. 44, No. 1, pp 3-22, 2013, https://doi.org/10.1080/00049182.2013.765345

18. Sovacool, B., Running on Empty: The Electricity-water Nexus and the US Electric Utility Sector, Energy Law Journal, Vol. 30, No. 1, pp 11-51, 2009.

19. Siddiqi, A., Kajenthira, A. and Anadón, L., Bridging Decision Networks for Integrated Water and Energy Planning, Energy Strategies Reviews, Vol. 2, No. 1, pp 46-58, 2013, https://doi.org/10.1016/j.esr.2013.02.003

20. King, C., Stillwell, A., Twomey, K. and Webber, M., Coherence Between Water and Energy Policies, Natural Resources Journal, Vol. 53, No. 1, pp 117-215, 2013.

21. Kumar, A., Building Regulations Related to Energy and Water in Indian Hill Towns, Journal of Sustainable Development of Energy, Water and Environment Systems, Vol. 5, No. 4, pp 496-508, 2017, https://doi.org/10.13044/j.sdewes.d5.0161

22. Scott, C. A., Pierce, S. A., Pasqualetti, M. J., Jones, A. L., Montz, B. E. and Hoover, J. H., Policy and Institutional Dimensions of the Water-energy Nexus, Energy Policy, Vol. 39, No. 10, pp 6622-6630, 2011, https://doi.org/10.1016/j.enpol.2011.08.013

23. Peel, J., Regulation of the Nexus. Climate, Energy and Water: Managing Trade-offs, Seizing Opportunities (Climate, Energy and Water: Managing Trade-offs, Seizing Opportunities) (Pittock, J., Hussey, K. and Dovers, S., eds.), Cambridge University Press, Cambridge, United Kingdom, pp 155-171, 2015. 
24. Pittock, J., Orr, S., Stevens, L., Aheeyar, M. and Smith, M., Tackling Trade-offs in the Nexus of Water, Energy and Food, Aquatic Procedia, Vol. 5, pp 58-68, 2015, https://doi.org/10.1016/j.aqpro.2015.10.008

25. Bach, H., Bird, J., Clausen, T. J., Jensen, K. M., Lange, R. B., Taylor, R., Viriyasakultorn, V. and Wolf, A., Transboundary River Basin Management: Addressing Water, Energy and Food Security, Vientiane, LAO PDR, Mekong River Commission, 2012.

26. Weitz, N., Strambo, C., Kemp-Benedict, E. and Nilsson, M., Closing the Governance Gaps in the Water-energy-food Nexus: Insights from Integrative Governance, Global Environmental Change, Vol. 45, pp 165-173, 2017, https://doi.org/10.1016/j.gloenvcha.2017.06.006

27. Gassert, F., Reig, P., Luo, T. and Maddocks, A., Aqueduct Country and River Basin Rankings: A Weighted Aggregation of Spatially Distinct Hydrological Indicators, Working Paper, World Resources Institute, Washington, D. C., USA, 2013, http://wri .org/publication/aqueduct-country-river-basin-rankings, [Accessed: 03-June-2017]

28. Rodriguez, D., Delgado, A. and Lawford, R., Thirsty Energy, World Bank Water Papers, World Bank, Washington, D. C., USA, 2013.

29. International Energy Agency (IEA), World Energy Outlook, OECD, Paris, France, 2012.

30. United Nations Department of Economic and Social Affairs (UN DESA), The 2018 Revision of the World Urbanization Prospects, Press Release, 2018, https://esa.un.org/unpd/wup/Publications/Files/WUP2018-PressRelease.pdf, [Accessed: 16-August-2018]

31. National Energy Council (CNPE), Resolution No. 3, Introduction of New Risk Aversion Mechanisms in Energy Model, Brazil, 2013, http://www.mme.gov.br/documents/10584/1139163/Resoluxo_CNPE_Nx_3_2013_ NR.pdf/a6476730-0c23-4a59-8a87-881f7c6d895b, [Accessed: 03-March-2017]

32. Energy Research Company (EPE), Ten-year Expansion Plan 2024, Brazil, http://www.epe.gov.br/pt/publicacoes-dados-abertos/publicacoes/plano-decenal-de-e xpansao-de-energia-pde, [Accessed: 03-February-2016]

33. Energy Research Company (EPE), National Energy Balance 2017: Base-line Year 2016, Brazil, https://ben.epe.gov.br/BENRelatorioFinal.aspx?anoColeta $=2017 \&$ anoFimColeta=2016, [Accessed: 03-June-2018]

34. National Council for Energy Policy (CNPE), Resolution No. 1, Defines the Criteria for Supply Security Applicable to Studies Informing Planning and Operation of the Electricity System, Brazil, 2004, http://www.mme.gov.br/documents/10584/1139145/Resolucao01.pdf/fe3dbb77-16c c-4ba6-b4de-37d1e0e3a93e, [Accessed: 03-January-2017]

35. National System Operator (ONS), Maps and Information of Electricity System of Brazil, Brazil, http://ons.org.br/pt/paginas/sobre-o-sin/mapas, [Accessed: 05-January-2018]

36. National Council for Energy Policy (CNPE), Resolution No. 7, Defines One Level of Energy Deficit Cost Valid from January 2017, Brazil, 2016, http://www.mme. gov.br/documents/10584/3201726/Resolu\%C3\%A7\%C3\%A3o_7_CNPE_CPAMP. pdf/21197890-8ef1-4f5f-aa94-f674b8aaa06f, [Accessed: 03-March-2018]

37. National Electric Energy Agency (ANEEL), Resolution Homologotary 1837, Approves the Four Tiers of Energy Deficit Risk for the Year of 2015, Brazil, 2014, http://www2.aneel.gov.br/cedoc/reh20141837.pdf, [Accessed: 03-March-2018]

38. Electric Energy Trading Chamber (CCEE), Market Information - Download of Reports, Brazil, https://www.ccee.org.br/portal/faces/pages_publico/o-que-fazemos/ infomercado?showFlag=F\&_afrLoop=19953231656612\#!\%40\%40\%3F_afrLoop\% 
3D19953231656612\%26showFlag\%3DF\%26_adf.ctrl-state\%3D18qj5eedfr_9,

[Accessed: 04-June-2018]

39. National Electric Energy Agency (ANEEL), Tariffs Activation History until March 2015, Brazil, http://www.aneel.gov.br/documents/654800/14867739/Relatorio_do_ Acionamento_das_Bandeiras_Tarifarias_at\%C3\%A9_mar\%C3\%A7o2015.pdf/1ffa 7c80-adf4-9073-2674-5de62341b55, [Accessed: 03-January-2017]

40. Civil House of the Presidency of the Republic, Decree 8.401, Centralises Funds Collected Through the Coloured Flag Tariffs under a Common Account, Brazil, 2015, http://www.planalto.gov.br/ccivil_03/_Ato2015-2018/2015/Decreto/D8401 .htm, [Accessed: 06-August-2017]

41. National Electric Energy Agency (ANEEL), Explanatory Note: Calculation of the October / 2017 Flag Account, Brazil, http://www.aneel.gov.br/documents/654800/ 16006265/Nota+Explicativa+outubro+2017-1.pdf/502f9f69-3d64-24e3-b916-9581a ce59616, [Accessed: 03-February-2018]

42. National System Operator (ONS), Energy Now: Reservoirs, Brazil, http://www.ons. org.br/paginas/energia-agora/reservatorios, [Accessed: 04-April-2018]

43. National Water Agency (ANA) (Brazil), Critical Events Room for the São Francisco, http://www3.ana.gov.br/portal/ANA/sala-de-situacao/sao-francisco/sao-francisco-sa iba-mais, [Accessed: 07-August-2018]

44. National Water Agency (ANA), Resolution No. 442, Authorization to Reduce the Minimum Water Discharge Levels for Sobradinho and Xingó from 1,300 to 1,100 $\mathrm{m}^{3} / \mathrm{s}$, Brazil, 2013, http://arquivos.ana.gov.br/resolucoes/2013/442-2013.pdf, [Accessed: 13-September-2018]

45. National Water Agency (ANA), Resolution No. 713, Authorization to Reduce the Minimum Water Discharge Levels for Sobradinho and Xingó to $900 \mathrm{~m}^{3} / \mathrm{s}$, Brazil, 2015, http://arquivos.ana.gov.br/resolucoes/2015/713-2015.pdf, [Accessed: 13-September-2018]

46. National Water Agency (ANA), Resolution No. 66, Authorization to Reduce Minimum Water Discharge Level for Sobradinho and Xingó to $800 \mathrm{~m}^{3} / \mathrm{s}$, Brazil, 2016, http://arquivos.ana.gov.br/resolucoes/2016/66-2016.pdf, [Accessed: 13-September-2018]

47. National Water Agency (ANA), Resolution No. 1,283, Authorization to Reduce Minimum Water Discharge Level for Sobradinho and Xingó to $700 \mathrm{~m}^{3} / \mathrm{s}$, Brazil, 2016 , http://arquivos.ana.gov.br/resolucoes/2016/1283-2016.pdf, [Accessed: 13-September-2018]

48. National Water Agency (ANA), Resolution No. 1943, Authorization to Reduce Minimum Water Discharge Level for Sobradinho and Xingó to 550/523 $\mathrm{m}^{3} / \mathrm{s}$, Brazil, 2017, http://arquivos.ana.gov.br/resolucoes/2017/1943-2017.pdf, [Accessed: 13-September-2018]

49. National Water Agency (ANA), Critical Events Room for the Paraíba do Sul, Brazil, http://www3.ana.gov.br/portal/ANA/sala-de-situacao/paraiba-do-sul/paraiba-do-sulsaiba-mais, [Accessed: 13-September-2018]

50. National Water Agency (ANA), Critical Events Room for the Tocantins Basin, Brazil, http://www3.ana.gov.br/portal/ANA/sala-de-situacao/tocantins/saiba-maistocantins, [Accessed: 13-September-2018]

51. Civil House of the Presidency of the Republic, Law 13.203, Regulates the Transferring of the Hydrological Risk to Consumers, Brazil, 2015, http://www.planalto.gov.br/ccivil_03/_Ato2015-2018/2015/Lei/ L13203.htm, [Accessed: 13-September-2018]

52. Civil House of the Presidency of the Republic, Law No. 12.783, Disciplines the Renewal of Concession Generation Agreements and Affordable Tariffs, 
Brazil, 2013, http://www.planalto.gov.br/ccivil_03/_ato2011-2014/2013/Lei/ L12783.htm, [Accessed: 13-September-2018]

53. National Electric Energy Agency (ANEEL), Schedule and Results of Tariff Distribution Processes, Brazil, 2016, http://www.aneel.gov.br/resultado-dosprocessos-tarifarios-de-distribuicao, [Accessed: 13-September-2018]

54. Mendes, A. L. S., de Castro, N., Brandão, R., Câmara, L. and Moszkowicz, M., The Role of Imbalance Settlement Mechanisms in Electricity Markets: A Comparative Analysis Between UK and Brazil, Proceedings of the $13^{\text {th }}$ International Conference on the European Energy Market (EEM), Porto, Portugal, pp 1-6, 2016, https://doi.org/10.1109/EEM.2016.7521348

55. Klingberg, J., Energy, Water and Sanitation Governance, MS.c. Thesis, Estudos Sobre Economia, Meio Ambiente e Agricultura (Department CEEMA), University of Brasília, Brasilia, Brazil, 2016.

56. Ministry of Cities (SNSA), National Information System on Sanitation: Diagnosis of Water and Sewage Services, SNA/MCIDADE, Brasilia, Brazil, Brazil, 2016, http://www.snis.gov.br/diagnostico-agua-e-esgotos/diagnostico-ae2016, [Accessed: 13-September-2018]

57. Leite S., With Investments of the Casal, Piaçabuçu is Being Replenished Regularly, http://www.agenciaalagoas.al.gov.br/noticia/item/25118-com-investimentos-da-casa 1-piacabucu-volta-a-ser-abastecido-com-regularidade, [Accessed: 04-June-2018]

58. Sanitation Company of Alagoas (CASAL), Financial Statements for the Years Ended 31 December 2016 and 2015, Brazil, https://www.casal.al.gov.br/wp-content/ uploads/2017/12/Balano2016.pdf, [Accessed: 13-September-2018]

59. Sanitation Company of Alagoas (CASAL), Financial Statements for the Years Ended 31 December 2015 and 2014, Brazil, https://www.casal.al.gov.br/wp-content/ uploads/2017/12/CASAL201511.pdf, [Accessed: 13-September-2018]

60. Sergipe Sanitation Company (DESO), Financial Statements for the Year 2017, Brazil, https://www.deso-se.com.br/v2/images/documentos/demosntr_financ/Balano\%20D ESO\%20-\%20REF\%202017\%20-\%20Dirio.pdf, [Accessed: 13-September-2018]

61. Sergipe Sanitation Company (DESO), Financial Statements for the Year 2014, Brazil, https://www.deso-se.com.br/v2/images/documentos/demosntr_financ/deso-dou-201 5.pdf, [Accessed: 13-September-2018]

62. Sergipe Sanitation Company (DESO), Financial Statements for the Year 2015, Brazil, https://www.deso-se.com.br/v2/images/documentos/demosntr_financ/deso-DOU-20 16.pdf, [Accessed: 13-September-2018]

63. Bahia State Water and Sanitation Company S.A. (EMBASA), Management Report and Financial Statements 2015, Brazil, http://www.embasa.ba.gov.br/ sites/default/files/demonstracoes_financeiras/arquivos/2016/04/27/Relatorio_da_Ad ministracao_Embasa_2015\&Balanco.pdf, [Accessed: 13-September-2018]

64. Bahia State Water and Sanitation Company S.A. (EMBASA), Management Report and Financial Statements 2016, Brazil, http://www.embasa.ba.gov.br/sites /default/files/demonstracoes_financeiras/arquivos/2017/05/15/Relatorio_da_adminis tracao_Embasa_2016.pdf, [Accessed: 13-September-2018]

65. Andersson, K. P. and Ostrom, E., Analyzing Decentralized Resource Regimes from a Polycentric Perspective, Policy Sci., Vol. 41, No. 1, pp 71-93, 2008, https://doi.org/10.1007/s11077-007-9055-6

66. Braga, B., Flecha, R., Pena, D. and Kelman, J., Federative Pact and Water Management (in Portuguese), Estudos Avançados, Vol. 22, No. 63, pp 17-42, 2008, https://doi.org/10.1590/S0103-40142008000200003

67. Civil House of the Presidency of the Republic, Law No. 9.433 of January 8, 1997, National Water Policy, Brazil, http://www.planalto.gov.br/ccivil_03/Leis/19433.htm, [Accessed: 13-September-2018] 
68. Civil House of the Presidency of the Republic, Law No. 9.427 of December 26, 1996, Implements the National Electricity Regulatory Agency, Brazil, http://www. planalto.gov.br/ccivil_03/Leis/L9427cons.htm, [Accessed: 13-September-2018]

69. Brazilian Auditing Court (TCU), Decision 1171/2014 of Proceeding No. 012.949/2013-2, Decision Regarding Strong Evidence of Structural Issues Involving Energy Generation in Brazil, Brasília, Brazil, 2014, https://contas.tcu.gov.br/etcu/ObterDocumentoSisdoc?seAbrirDocNoBrowser=true $\&$ codArqCatalogado=10140631, [Accessed: 13-September-2018]

70. Hiteva, R. and Watson, J., Governance of Interdependent Networks (Hall, J. W., et al. eds.), The Future of National Infrastructure a System-of-Systems Approach, Cambridge University Press, Cambridge, United Kingdom, 2016, https://doi.org/10.1017/CBO9781107588745

71. Hajer, M., Policy without Polity? Policy Analysis and the Institutional Void, Policy Sciences, Vol. 36, No. 2, pp 175-195, 2003.

72. Fisher, B., Kulindwa, K., Mwanyoka, I., Turner, K. R. and Burgess, N. D., Common Pool Resource Management and PES: Lessons and Constraints for Water PES in Tanzania, Ecological Economics, Vol. 69, No. 6, pp 1253-1261, 2010, https://doi.org/10.1016/j.ecolecon.2009.11.008

73. Briassoulis, H., Policy Integration for Complex Policy Problems: What, Why and How, Proceedings of the Berlin Conference Greening of Policies: Interlinkages and Policy Integration, Berlin, Germany, 2004.

74. Romão, W. M., Reflections on the Difficulties of Implementing Institutional Participation in Brazil (in Portuguese), Idéias, Vol. 6, No. 2, p 35, 2016.

75. United Nations Inter-Agency and Expert Group on SDGs indicators, Tier Classification for Global SDG Indicators, 2016, https://unstats.un.org/sdgs/files/ meetings/iaeg-sdgs-meeting-, [Accessed: 03-December-2017]

76. Civil House of the Presidency of the Republic, Law No. 9.478, August 6, 1997, Energy Policy, D.O.U. of 7.8.1997, Brazil, http://www.planalto.gov.br/ccivil_03/ Leis/L9478.htm, [Accessed: 13-September-2018]

77. Civil House of the Presidency of the Republic, Law No. 10.295, 17 October 2001, National Policy for Conservation and Rational Use of Energy, D.O.U. of 18.10.2001, Brazil, http://www.planalto.gov.br/ccivil_03/leis/leis_2001/110295.htm, [Accessed: 13-September-2018]

78. Civil House of the Presidency of the Republic, Law No. 6.938, 31 August 1981, Brazil, National Environmental Policy, D.O.U. of 2.9.1981, http://www.planalto.gov .br/ccivil_03/Leis/L6938.htm, [Accessed: 13-September-2018]

79. Civil House of the Presidency of the Republic, Law No.11.455, 5 January 2007, National Sanitation Policy, D.O.U. of 8.1.2007, Brazil, http://www.planalto.gov. br/ccivil_03/_ato2007-2010/2007/lei/111445.htm, [Accessed: 13-September-2018]

80. Civil House of the Presidency of the Republic, Law No. 12.305, 2 August 2010, National Solid Waste Policy, D.O.U. of 3.8.2010, Brazil, http://www.planalto.gov.br/ ccivil_03/_ato2007-2010/2010/1ei/112305.htm, [Accessed: 13-September-2018]

81. Civil House of the Presidency of the Republic, Decree 8.243, 23 May 2014, National Policy for Public Participation, D.O.U. of 26.5.2014, Brazil, http://www.planalto.gov.br/ccivil_03/_ato2011-2014/2014/decreto/d8243.htm, [Accessed: 13-September-2018] 